Simposium I Jaringan Perguruan Tinggi untuk Pembangunan Infrastruktur Indonesia, 2016

\title{
Kajian Kapasitas Infrastruktur : Suatu Upaya Peningkatan Pariwisata Sumatera Barat
}

\author{
Yervi Hesna $^{\mathrm{a} *}$, Akhmad Suraji ${ }^{\mathrm{a}}$, Bambang Istijono ${ }^{\mathrm{a}}$, Benny Hidayat ${ }^{\mathrm{a}}$, Taufika Ophyandri ${ }^{\mathrm{a}}$ \\ ${ }^{a}$ Jurusan Teknik Sipil Universitas Andalas, Kampus Unand Limau Manis, Padang ,Indonesia
}

\begin{abstract}
Abstrak
Sinergi antara pemerintah pusat dan daerah, antara pemerintah dan dunia usaha, serta antardaerah sangat diperlukan dalam meningkatkan potensi keberhasilan pembangunan pariwisata berbasis kewilayahan. Kunci utama untuk menciptakan sebuah daerah dengan industri pariwisata yang baik adalah terwujudnya kenyamanan pengunjung. Kenyamanan pengunjung akan bisa terlaksana jika dua variabel berikut terpenuhi yakni adanya budaya dan perilaku masyarakat yang ramah pariwisata dan adanya infrastruktur yang saling berkesinambungan antar destinasi pariwisata. Untuk itu pemerintah pusat dan daerah harus bersama-sama mewujudkan adanya peningkatan infrastruktur kepariwisataan di provinsi Sumatera Barat. Walaupun kaya akan budaya dan kondisi alamnya nan cantik, tidak membuat provinsi Sumatera Barat kebanjiran kunjungan wisatawan. Bahkan untuk tahun 2015 lalu terjadi penurunan kunjungan wisatawan mancanegara sebanyak 13,2\%. Untuk itu promosi dan peningkatan infrastruktur pariwisata harus terus dilakukan. Untuk mewujudkan hal diatas, perlu kiranya untuk mengetahui kapasitas infrastruktur di Provinsi Sumatera Barat saat ini dalam rangka mendukung industry pariwisata. Ini dimaksudkan untuk mendapatkan benchamarking atau titik patok bagi pengembangan infrastruktur kedepannya dalam rangka peningkatan aksesibilitas pariwisata Sumatera Barat. Diharapkan dengan penelitian ini dapat mengetahui kondisi eksisting infrastruktur kepariwisataan provinsi Sumatera Barat dan bagaimana strategi pengembangannya kedepan sehingga bisa menambah kontribusi pendapatan daerah dari sektor pariwisata.
\end{abstract}

Keywords: Kapasitas; Infrastruktur; Pariwisata; Sumatera Barat

\section{Latar Belakang}

Ditengah lesunya ekonomi global dan regional, meningkatnya jumlah kunjungan turis mancanegara ke Indonesia seakan-akan memberi angin segar bahwa pariwisata dapat dijadikan ujung tombak untuk menggenjot devisa Negara. Badan Pusat Statistik merilis jumlah wisatawan mancanegara pada selama periode tahun 2015 tumbuh 3,12\% menjadi 9,73 juta orang dibandingkan dengan tahun sebelumnya. Bahkan pemerintah telah menjadikan bahwa industri pariwisata menjadi satu dari lima sektor unggulan pemerintah dalam mendatangkan devisa.

Saat ini memang pariwisata baru menempati peringkat keempat dari penyumbang devisa Negara setelah bidang oil and gas, coal, dan crude palm oil. Tidak hanya dari devisa, industri pariwisata memberikan multiplier effect terhadap masyarakat sekitar. Industri perhotelan, industri kreatif seperti kuliner dan cinderamata merupakan industri yang banyak menyerap tenaga kerja untuk menikmati berkah dari pariwisata. Pada tahun 2020 nanti, pemerintah menargetkan sekitar 20 juta orang wisatawan mancanegara datang ke Indonesia. Dan tidak mungkin pariwisata akan menjadi sektor utama pendapatan Negara.

Dibandingkan dengan provinsi tetangga, provinsi Sumatera Barat termasuk provinsi yang paling lengkap destinasi wisatanya. Tidak ada yang meragukan keindahan alam, kekayaan budaya dan kuliner Sumatera Barat. Berita Resmi Statistik Badan Pusat Statistik (BPS) Provinsi Sumatera Barat mencatat jumlah kunjungan wisatawan mancanegara sepanjang tahun 2015 adalah 48.755 orang. Menurun 13,1 persen dibandingkan periode yang sama pada tahun sebelumnya. Hal ini menjadi bertolak belakang dengan kondisi pariwisata Indonesia secara keseluruhan. Wisatawan yang berkunjung ke Sumatera Barat hanya memberikan kontribusi sebesar 0,5 persen terhadap total wisatawan mancanegara yang berkunjung ke Indonesia.

Pemerintah Provinsi Sumatera Barat sudah menetapkan pariwisata sebagai sektor unggulan untuk lima tahun kedepan karena diyakini industri pariwisata dapat memajukan kesejahteraan masyarakatnya. Sebagai salah satu contoh adalah kota Sawahlunto yang bermetamorfosa dari kota tambang menjadi kota pariwisata sehingga dinobatkan menjadi kota dengan tingkat kemiskinan paling rendah setelah Denpasar.

Kunci utama untuk menciptakan sebuah daerah dengan industry pariwisata yang baik adalah terwujudnya kenyamanan pengunjung. Kenyamanan pengunjung akan bisa terlaksana jika dua variabel berikut terpenuhi yakni adanya budaya dan perilaku masyarakat yang ramah pariwisata dan adanya infrastruktur yang saling berkesinambungan antar destinasi pariwisata. 
Sebagai salah satu contoh adalah Kabupaten Pesisir Selatan dan Kabupaten Solok. Destinasi pariwisata yang terdapat di kedua kabupaten ini tidak mempunyai infrastruktur yang saling berhubungan sehingga jika wisatawan ingin berkunjung ke daerah Kabupaten Solok setelah berpuas diri menikmati Kabupaten Pesisir Selatan, maka wisatawan harus kembali melewati Kota Padang. Hingga saat ini hanya Kota Padang dan Kota Bukittingi yang dianggap mempunyai infrastruktur yang baik guna menunjang industri pariwisata.

Pada tanggal 6 Juni 2014 telah diterbitkan Peraturan Daerah Provinsi Sumatera Barat Nomor 3 Tahun 2014 tentang Rencana Induk Pembangunan Kepariwisataan (RIPK) Propinsi Sumatera Barat Tahun 2014-2025, diharapkan dapat menyelaraskan pembangunan kepariwisataan dan dijadikan pedoman bagi pemerintah daerah untuk mengembangkan kepariwisataan di daerahnya.

Ada empat aspek yang diatur dalam RIPK Provinsi Sumatera Barat, yakni a) Pembangunan destinasi pariwisata; b) pembangunan pemasaran pariwisata; c) pembangunan industry pariwisata; dan d) pembangunan kelembagaan kepariwisataan. Beberapa aspek yang harus diwujudkan untuk membangun destinasi pariwisata diantaranya adalah ketersediaan aksesibilitas pariwisata dan adanya prasarana umum, fasilitas umm dan fasilitas pariwisata yang cukup secara kualitas dan kuantitas. Pembangunan aksesibilitas pariwisata dapat dilakukan dengan menyediakan dan mengembangkan sarana, prasarana dan system tranportasi. Dengan begitu, kemudahan akses dan pergerakan wisatawan menuju destinasi pariwisata, serta keamanan dan kenyamanan bagi wisatawan bisa didapat.

Untuk mewujudkan hal diatas, perlu kiranya untuk mengetahui kapasitas infrastruktur di Provinsi Sumatera Barat saat ini dalam rangka mendukung industry pariwisata. Ini dimaksudkan untuk mendapatkan benchamarking atau titik patok bagi pengembangan infrastruktur kedepannya dalam rangka peningkatan aksesibilitas pariwisata Sumatera Barat.

Melalui penelitian ini perlu untuk melihat seperti apa kondisi/kapasitas infrastruktur pada setiap kota/kabupaten di Sumatera Barat dan kecukupan dari infrastructure stock capacity sebai pembangkit perekonomian melalui industry pariwisata.. Sehingga nantinya diharapkan dari penelitian ini akan terwujud pemetaan kondisi infrastruktur pariwisata pada setiap daerah kota/kabupaten dan analisis berkenaan dengan kesenajangan (gap) infrastruktur yang terjadi pada setiap daerah.

Dengan adanya pemetaan dan analisis gab infrastruktur tersebut dapat membantu Pemerintah Provinsi Sumatera Barat dan pemerintah kota/kabupaten khususnya dalam merencanakan pembangunan infrastruktur pariwisata sehingga terciptanya konsep pariwisata Sumatera Barat yang jelas dan matang.

\section{Kondisi Existing Infrastruktur di Provinsi Sumbar}

Infrastruktur yang ada di Provinsi Sumbar yang sangat terkait dengan kepariwisataan, yaitu infrastruktur transportasi, yang terdiri dari transportasi udara, laut, dan darat; serta hotel dan rumah makan. Ketersediaan infrastruktur transportasi, yang dapat diukur dari kemudahan dan kelancaran aksesibilitas menuju suatu destinasi wisata tertentu, merupakan salah satu faktor utama penentu kesuksesan pengembangan suatu objek pariwisata.

Secara umum, aksesibilitas menuju dan keluar dari Sumatera Barat sudah sangat bagus. Provinsi Sumbar memiliki sebuah bandara internasional (Bandara International Minangkabau/BIM) yang melayani baik penerbangan domestik maupun international secara berkala. Penerbangan domestik dilayani oleh 6 maskapai dan internasional oleh 1 maskapai. Pada saat ini penerbangan langsung (direct flights) dari BIM tersedia ke Jakarta, Bandung, Batam, Medan, Mentawai, dan Kuala Lumpur. Jumlah penerbangan domestik dari BIM menuju kota yang dituliskan di atas mencapai 195 penerbangan dalam satu minggu dan untuk penerbangan international sebanyak 14 penerbangan per minggu [1]. Kepulauan Mentawai sebagai salah satu destinasi wisata unggulan Provinsi Sumbar juga bisa dijangkau dengan transportasi udara. Penerbangan ke Kepulauan Mentawai dilayani oleh sebuah maskapai dengan frekuensi satu kali penerbangan per hari dari BIM.

Sarana dan prasarana transportasi laut juga sangat mendukung kemajuan kepariwisataan di Provinsi Sumatera Barat. Pelabuhan Teluk Bayur merupakan sebuah pelabuhan samudera yang sanggup disandaru oleh kapal bertonase besar, seperti kapal pesiar. Akan tetapi pelabuhan ini kurang termanfaatkan dengan baik terbukti dengan sangat kecilnya jumlah penumpang (1300 penumpang per tahun) yang dilayani oleh pelabuhan. Transportasi antar pulau, terutama ke Kepulauan Mentawai, lebih banyak dilayani oleh pelabuhan Bungus dan pelabuhan Batang Arau. Wisatawan yang akan ke Kepulauan Mentawai untuk surfing biasanya akan menggunakan kapal carteran yang dilayani oleh sektor swasta melalu travel agent.

Destinasi wisata utama yang terdapat di daratan pada umumnya dapat dijangkau dengan mudah melalui transportasi darat. Menurut data statistik tahun 2014, panjang jalan negara, jalan provinsi, dan jalan kabupaten/kota yang ada di Sumbar adalah sepanjang $1212 \mathrm{~km}, 1230 \mathrm{~km}$, dan $19834 \mathrm{~km}$ secara berurutan. Prosentase kondisi jalan yang berada dalam keadaan mantap 
sangat bagus, mencapai 98,60 \% untuk jalan nasional dan 82,68\% untuk jalan provinsi. Akan tetapi, jika diperhatikan pada hari libur besar, aksesibilitas menuju destinasi wisata akan sedikit terhambat akibat terjadinya kemacetan. Untuk itu, opsi untuk pelebaran jalan dan atau pengaturan lalu lintas menuju destinasi wisata perlu menjadi perhatian pemerintah dan seluruh pemangku kepentingan untuk mendukung kelancaran dan kemudahan menuju objek wisata.

Konektifitas antar daerah juga mempunyai permasalahan. Sebagai salah satu contoh adalah Kabupaten Pesisir Selatan dan Kabupaten Solok. Destinasi pariwisata yang terdapat di kedua kabupaten ini tidak mempunyai infrastruktur yang saling berhubungan sehingga jika wisatawan ingin berkunjung ke daerah Kabupaten Solok setelah berpuas diri menikmati Kabupaten Pesisir Selatan, maka wisatawan harus kembali melewati Kota Padang. Hingga saat ini hanya Kota Padang dan Kota Bukittingi yang dianggap mempunyai infrastruktur yang baik guna menunjang industri pariwisata.

Selain itu, pemerintah telah sedang berusaha untuk menghidupkan kembali jalur rel kereta api yang telah lama mati. Jalur Padang menuju Padangpanjang, Bukittinggi, dan Payakumbuh telah mulai diperbaiki kembali. Jika nantinya jalur kereta api ini sudah bisa dilalui kembali, maka denyut kepariwisataan di Sumatera Barat akan semakin kuat.

Dari uraian di atas, maka dapat ditarik suatu kesimpulan bahwa sektor transportasi eksisting sangat mendukung kepariwisataan di Sumatera Barat. Akan tetapi, layanan transportasi antar moda masih perlu lebih diperhatikan. Sebagai contoh, konektivitas antara moda udara dan moda darat yang akan langsung mengantar wisatawan menuju destinasi wisata perlu dibenahi dengan baik.

Sebagai tambahan, selain sektor transportasi, infrastruktur pendukung lain yang utama dalam kepariwisataan adalah ketersediaan akomodasi/kamar hotel dan rumah makan. Ketersediaan hotel di Sumatera Barat cukup baik. Pada tahun 2015, jumlah hotel berbintang yang tersedia adalah sebanyak 60 hotel dengan jumlah kamar 3611 dan 5924 tempat tidur [2]. Tingkat hunian hotel berbintang mencapai 50,22\% pada tahun 2013 dengan rata-rata lama tamu menginap selama 1,50 hari.

Sebagai suatu daerah yang sangat terkenal dengan wisata kulinernya, ketersedian rumah makan dengan berbagai macam variasi makanan tradisional sudah tidak perlu diragukan lagi. Rumah makan dapat dijumpai dengan mudah, baik di destinasi wisata yang dituju maupun di sepanjang perjalanan menuju destinasi wisata tersebut. Akan tetapi, hal perlu dibenahi adalah kebersihan rumah makan serta ketersediaan informasi harga makanan. Sudah menjadi rahasia umum, pada hari libur besar nasional harga makanan meningkat sangat tajam dan kadang di luar batas kewajaran. Dengan ketersediaan informasi diharapkan ini tidak mendatangkan kekecewaan pada wisatawan yang berkunjung.

\section{Metode Penelitian}

Kerangka survey untuk penelitian ini diperlihatkan pada Error! Reference source not found. di bawah ini. Secara umum langkahlangkah dalam penelitian ini, seperti tercantum pada kerangka penelitian, adalah 1. Mengidentifikasi destinasi wisata (termasuk yang potensial) di Sumbar; 2. Mengidentifikasi kinerja destinasi wisata dan infrastruktur penunjang terpasang pada saat ini; 3. Menyusun strategi pengembangan infrastruktur kepariwisataan; 4. Menyusun strategi pembiayaan infrastruktur; dan hasil penelitian ini bisa dikembangkan lebih lanjut ke 5. Penyusunan master plan infrastruktur kepariwisataan di Sumbar. 


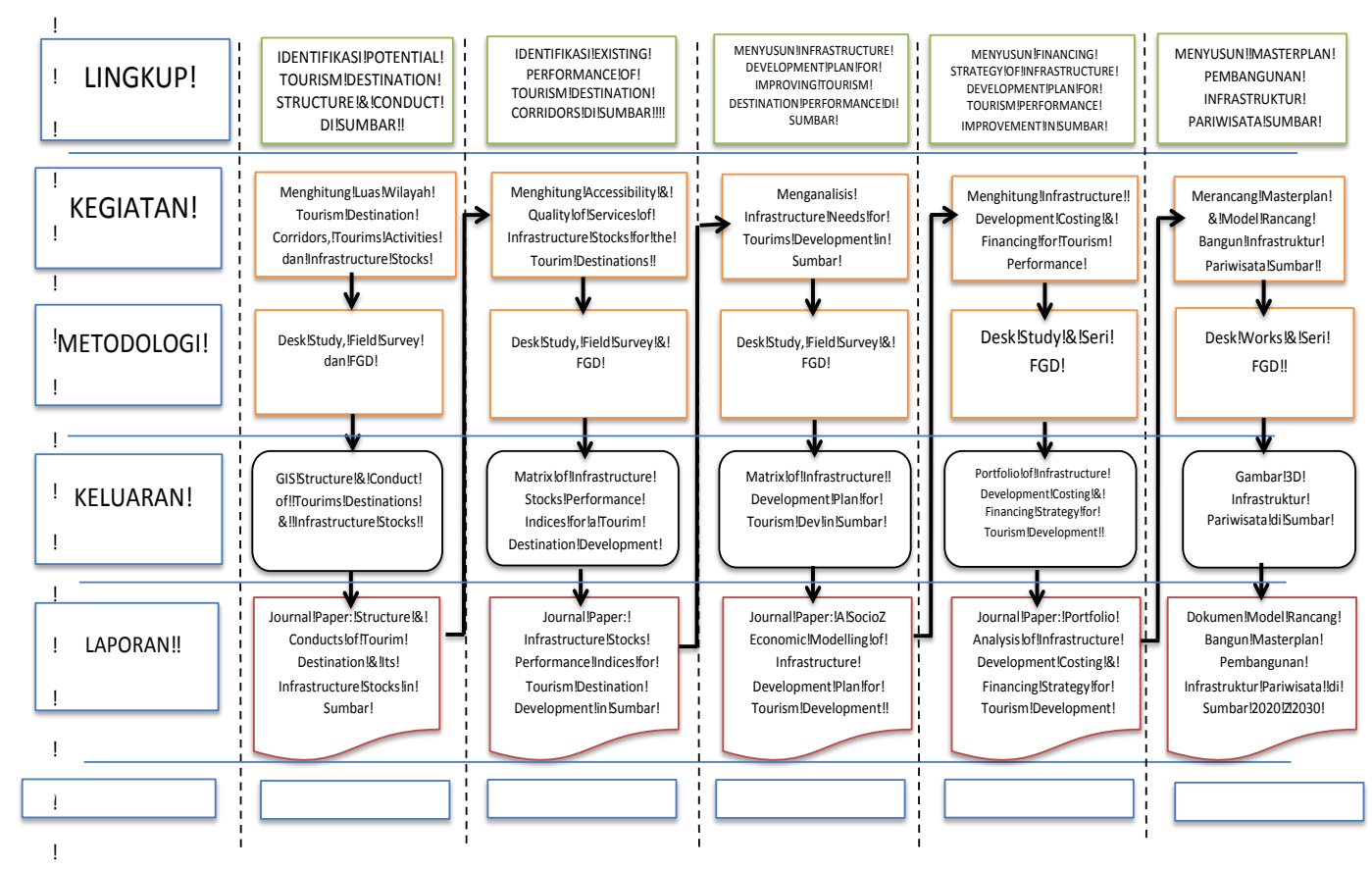

Gambar 1. Research framework

Data-data yang dihimpun dalam penelitian ini selanjutnya akan dianalisa dengan menggunakan berbagai metoda, seperti disajikan pada 1 berikut:

\section{Tabel 1. Analisa data}

\begin{tabular}{|c|c|c|c|}
\hline No & Data & Metoda Analisis & Hasil Analisis \\
\hline 1 & Luas Daerah Tujuan Wisata & $\begin{array}{ll}- & \text { Perhitungan Deskriptif }\end{array}$ & $\begin{array}{ll} & \text { Matrik Luas Wilayah Pariwisata } \\
\text { - } & \text { Potensi Pengembangan Wilayah Wisata }\end{array}$ \\
\hline 2 & Kegiatan Wisata & $\begin{array}{ll}- & \text { Perhitungan Deskriptif }\end{array}$ & $\begin{array}{ll}- & \text { Matrik Aktifitas Wisata } \\
- & \text { Potensi Pengembangan Aktifitas Wisata }\end{array}$ \\
\hline 3 & Infrastructure Stocks & - $\quad$ Perhitungan Deskriptif & $\begin{array}{ll}- & \text { Matrik Struktur dari Infrastruktur Stocks } \\
- & \text { Ketimpangan Infrastruktur Pariwisata }\end{array}$ \\
\hline 4 & $\begin{array}{l}\text { Kekuatan, Kelemahan, Peluang dan } \\
\text { Tantangan Pengembangan } \\
\text { Infrastruktur Pariwisata Sumbar }\end{array}$ & SWOT Analysis & $\begin{array}{ll}\text { - } & \text { Matrik Strategi Pengembangan Infrastruktur } \\
& \text { Pariwisata } \\
\text { - } & \text { Posisi Kwadran/ Kapasitas Wilayah Wisata }\end{array}$ \\
\hline 5 & Aksesibilitas Wilayah & $\begin{array}{llr}- & \text { Model } & \text { Formula } \\
& \text { Aksesibilitas Wilayah }\end{array}$ & $\begin{array}{ll}- & \text { Matrik Indeks Aksesibilitas Wilayah Pariwisata } \\
\text { - } & \text { Ketimpangan Aksesibilitas Wilayah }\end{array}$ \\
\hline 6 & Kualitas Layanan Infrastruktur & $\begin{array}{lll}- & \text { Model } & \text { Formula } \\
& \text { Kualitas Layanan, } \\
- & \text { Factor } & \text { Analysis } \\
& \text { Penentu Kualitas } \\
& \text { Layanan Infrastruktur, } \\
- & \text { Structural Equation } \\
& \text { Modelling (SEM) }\end{array}$ & $\begin{array}{ll} & \text { Kinerja Layanan Infrastruktur Pariwisata, } \\
\text { - } & \text { Matrik Kualitas Layanan Infrastruktur Pariwisata, } \\
\text { - } & \text { Penentu / Determinant Factors Layanan } \\
& \text { Infrastruktur Pariwisata }\end{array}$ \\
\hline
\end{tabular}




\section{Penutup}

Berkembangnya potensi daerah sesuai dengan keunikannya masing-masing berpotensi memperkuat struktur perekonomian nasional dan mengurangi kesenjangan antarwilayah. Pengembangan sektor pariwisata memiliki peran strategis dalam meningkatkan pertumbuhan ekonomi dan dalam upaya pemerataan pembangunan antarwilayah. Untuk menciptakan pembangunan kepariwisataan yang berkelanjutan maka harus dimulai dari pemahaman kondisi eksisting infrastruktur pariwisata yang ada. Dengan dasar tersebut nantinya bisa tercipta master plan pembangunan infrastruktur pariwisata guna mendukung pengembangan ekonomi daerah. Makalah ini merupakan rangkaian pendahuluan dari penelitian yang akan dilakukan oleh Kelompok Keahlian Manajemen Konstruksi dan Infrastruktur Jurusan Teknik Sipil Universitas Andalas pada pertengahan tahun ini.

\section{Acknowledgements}

Makalah ini merupakan pendahuluan dari penelitian yang dibiayai oleh Dana BOPTN Universitas Andalas tahun 2016

\section{References}

[1] BPS, “Sumatera Barat Dalam Angka 2014,” 2015.

[2] Badan Pusat Statistik, "Jumlah Akomodasi, Rata-rata Pekerja dan Jumlah Tamu per Hari Menurut Provinsi, Tahun 2016 (Hotel Bintang), 2016. [Online]. Available: https://www.bps.go.id/linkTabelStatis/view/id/1373. 